\title{
A Study of Determinants of Obesity - Is Skipping Breakfast Meal a Risk Factor?
}

\author{
Vinoth Gnana Chellaiyan ${ }^{1}$, Bhushan Dattatray Kamble², Raja T.K. ${ }^{3}$, Fasna Liaquathali", \\ Ria Saha ${ }^{5}$, Sunil Kumar Singh ${ }^{6}$, Bhabani Prasad Acharya ${ }^{7}$
}

${ }^{1,3}$ Department of Community Medicine, Chettinad Hospital and Research Institute, Chettinad Academy of Research and Education (CARE), Kelambakkam, Chennai, Tamil nadu, India, ${ }^{2}$ Department of Community Medicine \& Family Medicine, All India Institute of Medical Sciences, Bibinagar, Hyderabad Metropolitan Region, Telangana. India, ${ }^{4}$ NHM, Udhagamandalam, Tamil nadu, India, ${ }^{5}$ Independent Global Health Research, Clements Mansions, Lille Road London, UK. 6

Department of Community Medicine, North DMC Medical College and Hindu Rao Hospital, Delhi, India, ${ }^{7}$ Department of Community Medicine, University College of Medical Sciences, Delhi University, Dilshad Garden Delhi, India.

\section{ABSTRACT}

\section{BACKGROUND}

Breakfast is an important meal since it refuels the body after long night fasting. Regular intake of breakfast must have favourable supply of both micronutrients and macronutrients to maintain a body mass index (BMI) in the normal range. Despite its importance, the rate of skipping breakfast is observed to be alarmingly increasing among medical students. Therefore, the present study was undertaken to understand the dietary patterns, and physical activity level, and analyse the association of skipping breakfast with obesity among medical students.

\section{METHODS}

A cross-sectional study was conducted among 174 medical undergraduate students aged between 18 and 23 years in a tertiary care teaching hospital from August 2019 to October 2019. A pretested, semi-structured, validated, self-administered questionnaire was used to assess the profile, physical activity, food consumption pattern, and perception about the importance of breakfast meal. Regression analysis was done. Odds ratio was calculated.

\section{RESULTS}

About $23.6 \%$ and $27 \%$ of the study participants were found to be overweight and obese respectively. Only $51.1 \%$ of study participants were involved in physical activity. $17.2 \%$ of medical students skipped their breakfast regularly and $71.6 \%$ were aware that skipping breakfast would affect work efficacy and span of concentration. Age group of 22 - 23 years (OR: 19.5, $95 \% \mathrm{CI} ; 2.08,183.70$ ) was significantly associated with obesity. Skipping breakfast (OR, 0.45, $95 \% \mathrm{CI}: 0.23$, 0.90 ) was not found to be associated with obesity.

\section{CONCLUSIONS}

Our study found that more than one fourth participants were obese and one third were skipping breakfast daily or more than thrice a week. There was no association between obesity and skipping of breakfast meal. However, the importance of breakfast meal in a day cannot be ignored. Awareness programs to practice healthy eating habits might help in prevention of obesity and overweight among students.

\section{KEY WORDS}

Breakfast, Exercise, Obesity, Body Mass Index, Students, Medical

\author{
Corresponding Author: \\ Dr. Vinoth Gnana Chellaiyan, \\ Chettinad Hospital \& Research Institute, \\ Chettinad Academy of Research and \\ Education, Chettinad Health City, \\ Kelambakkam - 603103, Chengalpet \\ District, Tamil nadu, India. \\ E-mail: drchellaiyan@gmail.com
}

DOI: $10.14260 / j e m d s / 2021 / 389$

How to Cite This Article:

Chellaiyan VG, Kamble BD, Raja TK, et al. A study of determinants of obesity - is skipping breakfast meal a risk factor? J Evolution Med Dent Sci 2021;10(25):18831888, DOI: $10.14260 /$ jemds/2021/389

Submission 04-02-2021,

Peer Review 19-04-2021,

Acceptance 28-04-2021,

Published 21-06-2021.

Copyright (C) 2021 Vinoth Gnana Chellaiyan et al. This is an open access article distributed under Creative Commons Attribution License [Attribution 4.0 International (CC BY 4.0)] 


\section{BACKGROUND}

Universally breakfast is defined as the "the first meal of the day," which is consistent with the etymology to "break" the "fast". It is the "the first meal of the day" consumed within two hours of waking, before starting daily activities. According to American Heart Association report 2017, breakfast consumers tend to have lower rates of heart disease, high blood pressure, and high cholesterol. However, skipping meals has become an increasingly popular part of modern life, especially among young adults. ${ }^{1}$ Breakfast contains $20 \%-35$ $\%$ of daily energy needs and is considered to be the most important meal of the day as part of a healthy balanced diet.2,3 Breakfast habits are significantly associated with physiological, psychological, and social health dimensions. ${ }^{4}$ Evidence shows that meal skipping rates are generally highest during young adulthood, a period of transition and development. ${ }^{5}$ Silliman et al. and Sakamaki et al. reported a high prevalence (24\% - $87 \%$ ) of meal skipping habit among young adult population.6,7 Other studies reported that the frequency of recurrent missed breakfast among different age groups was higher than lunch and dinner.8,9 Evidence showed statistically significant associations between breakfast skipping and fatigue at noon worsens memory and higher body mass index as well as increased prevalence of obesity related chronic illness. ${ }^{10-12}$ Skipping breakfast has a greater influence on both waist circumference and BMI than eating dinner within three hours before sleep. ${ }^{13}$ A strong and congruous relationship between breakfast skipping and obesity, but not overweight, reported among children in the south eastern European population. ${ }^{14}$ Medical students are prone to skip meal due to hectic schedule and exposed to various infections during clinical postings. To date, there have been few studies conducted to determine the effect of skipping meal among medical students as discussed above. However, until now to the best of our knowledge, no study has been conducted to assess the association of skipping breakfast with obesity and its determinants.

\section{Objectives}

- To assess the determinants of obesity among medical students, including skipping breakfast meal and understand the perception about the importance of breakfast meal.

- To understand the dietary patterns, physical activity level and analyse the association of skipping breakfast with obesity among medical students.

\section{METHODS}

A cross-sectional study was conducted among medical school students in a tertiary care teaching hospital of Chennai, Tamil Nadu, India, for a period of 3 months from August 2019 to October 2019. The study population consisted of first to final academic year medical students pursuing Bachelor of Medicine and Bachelor of Surgery (MBBS). Students who were $\geq 18$ years of age and willing to participate in the study were included and studied. The students who could not be followed up after three attempts were excluded from the current study.

\section{Ethical Considerations}

The study was conducted after receiving approval from Institutional Ethics Committee. Written informed consent was obtained from all the participants prior to the start of the study. All personal identifying information was kept confidential.

\section{Sample size Calculation}

Sample size was calculated assuming the proportion of prevalence of obesity among medical school students as $30 \%$ as per Boo NY et al. ${ }^{15}$ The other parameters considered for sample size calculation were $5 \%$ absolute precision and 1.960 $\%$ confidence level. The following formula was used for sample size calculation as per Daniel WW et al. ${ }^{16}$

$\mathrm{N}=4 \mathrm{pq} / \mathrm{d}^{2}$

Where $\mathrm{n}=$ Sample size

$\mathrm{Z}=\mathrm{Z}$ statistic for a level of confidence level $=1.960$

$\mathrm{P}=$ Expected prevalence $/$ proportion of outcome $=0.3$

$\mathrm{d}=$ Precision $=0.07$

The required sample size as per the above mentioned calculation was 171 .

The final sample size included in the study was 174 .

\section{Sampling}

Stratified random sampling was done and 174 medical students were included from I to IV - year undergraduate class. The student's / study subjects were randomly selected by lottery method assigning numbers as per attendance roll numbers. Overall, 43 students were included from first and second year and 44 students were included from third and fourth year.

\section{Study Tool}

A pre tested, semi - structured questionnaire was used for data collection. The questionnaire was designed and validated by the authors of this study. At the initial phase of the study, a pilot testing was deployed with $10 \%$ of the study population. The questionnaire had separate sections which included specific details about profile, anthropometry, physical activity pattern, food consumption pattern, and perception about the importance of the breakfast meal.

\section{Statistical Analysis}

Data was first entered into Microsoft excel Spread Sheet and after checking the normality, the data was analysed using STATA. ${ }^{13}$ Descriptive statistics were presented as percentages and Bivariate and multivariate regression analysis was done. Adjusted Odds ratio was calculated.

\section{RESULTS}

In the present study, 174 medical students were included. The majority of the study participants (63\%) were in $20-21$ age group and females were more than males (63.8 \% VS $36.2 \%$ ). The Mean $( \pm$ SD) age was 19.9 years $( \pm 0.90)$. 


\begin{tabular}{|c|c|c|c|}
\hline \multicolumn{2}{|c|}{ Variables } & Frequency & Percentage \\
\hline & $18-19$ & 59 & 34 \\
\hline \multirow[t]{2}{*}{ Age group (in years) } & $20-21$ & 109 & 63 \\
\hline & $22-23$ & 6 & 3.4 \\
\hline \multirow{2}{*}{ Gender } & Male & 63 & 36.2 \\
\hline & Female & 111 & 63.8 \\
\hline \multirow{2}{*}{ Place of Residence } & Hosteller & 84 & 48.3 \\
\hline & Day scholar & 90 & 51.7 \\
\hline \multirow{3}{*}{ Permanent Residence } & City & 135 & 78 \\
\hline & Town & 36 & 20.7 \\
\hline & Village & 3 & 1.7 \\
\hline \multirow{4}{*}{ Religion } & Hindu & 150 & 86 \\
\hline & Christian & 16 & 9.2 \\
\hline & Muslim & 7 & 4 \\
\hline & Jain & 1 & 1.6 \\
\hline \multirow{6}{*}{ Education of Father } & Illiterate & 3 & 1.7 \\
\hline & Primary & 1 & 0.6 \\
\hline & High school & 9 & 5.2 \\
\hline & Higher secondary & 12 & 6.9 \\
\hline & Graduate & 114 & 65.5 \\
\hline & Post Graduate & 35 & 20.1 \\
\hline \multirow{7}{*}{ Occupation of the father } & Unemployed & 1 & 0.6 \\
\hline & Unskilled & 1 & 0.6 \\
\hline & Semiskilled & 3 & 1.7 \\
\hline & Skilled & 7 & 4.0 \\
\hline & $\begin{array}{l}\text { Clerk, Shop owner, } \\
\text { farmer }\end{array}$ & 73 & 42. \\
\hline & Semi - professional & 51 & 29.3 \\
\hline & Professional & 38 & 21.8 \\
\hline \multirow{6}{*}{ Education of the mother } & Illiterate & 4 & 2.3 \\
\hline & Primary & 3 & 1.7 \\
\hline & High school & 20 & 11.5 \\
\hline & Higher secondary & 14 & 8 \\
\hline & Graduate & 111 & 63.8 \\
\hline & Post Graduate & 22 & 12.6 \\
\hline \multirow{6}{*}{$\begin{array}{l}\text { Occupation of the } \\
\text { mother }\end{array}$} & Unemployed & 114 & 65.5 \\
\hline & Semiskilled & 1 & 0.6 \\
\hline & Skilled & 9 & 5.2 \\
\hline & $\begin{array}{l}\text { Clerk, Shop owner, } \\
\text { farmer }\end{array}$ & 14 & 8.0 \\
\hline & Semi - professional & 11 & 6.3 \\
\hline & Professional & 25 & 14.4 \\
\hline \multirow{2}{*}{ Type of family } & Nuclear & 157 & 90.2 \\
\hline & Joint & 17 & 9.8 \\
\hline $\begin{array}{r}\text { Table 1. Distr } \\
\text { Den }\end{array}$ & $\begin{array}{l}\text { tion of the Study } \\
\text { raphic Characte }\end{array}$ & $\begin{array}{l}\text { cipants as } \\
S(N=174)\end{array}$ & Socio- \\
\hline
\end{tabular}

\begin{tabular}{|c|c|c|c|}
\hline \multicolumn{2}{|l|}{ Variables } & Frequency & Percentage \\
\hline \multirow{2}{*}{$\begin{array}{l}\text { Involved in physical activity }(\mathrm{N}= \\
94)\end{array}$} & Yes & 89 & 51.2 \\
\hline & No & 5 & 48.8 \\
\hline \multirow{4}{*}{$\begin{array}{l}\text { Frequency of moderate physical } \\
\text { activity }(\mathrm{N}=59)\end{array}$} & Daily & 16 & 27.1 \\
\hline & $\begin{array}{l}4 \text { - } 6 \text { day / } \\
\text { weeks }\end{array}$ & 19 & 32.2 \\
\hline & $\begin{array}{l}2 \text { - } 3 \text { days / } \\
\text { week }\end{array}$ & 21 & 35.6 \\
\hline & $\begin{array}{l}\text { One day / } \\
\text { week }\end{array}$ & 3 & 5.1 \\
\hline \multirow{4}{*}{$\begin{array}{l}\text { Duration involved in such } \\
\text { physical activity }(\mathrm{N}=59)\end{array}$} & $\begin{array}{l}>1 \text { hour / } \\
\text { day }\end{array}$ & 13 & 22 \\
\hline & $\begin{array}{l}45-60 \text { mins } \\
\text { / day }\end{array}$ & 18 & 30.5 \\
\hline & $\begin{array}{l}30-45 \text { mins } \\
\text { / day }\end{array}$ & 21 & 35.6 \\
\hline & $<\begin{array}{c}<0 \text { mins } / \\
\text { day }\end{array}$ & 07 & 11.9 \\
\hline \multirow{4}{*}{$\begin{array}{l}\text { Frequency of intense physical } \\
\text { activity }(\mathrm{N}=30)\end{array}$} & Daily & 5 & 17 \\
\hline & $\begin{array}{l}4-6 \text { days / } \\
\text { weeks }\end{array}$ & 8 & 27 \\
\hline & $\begin{array}{l}2 \text { - } 3 \text { days / } \\
\text { week }\end{array}$ & 6 & 20 \\
\hline & $\begin{array}{l}\text { One day / } \\
\text { week }\end{array}$ & 11 & 36 \\
\hline \multirow{4}{*}{$\begin{array}{l}\text { Duration involved in intense } \\
\text { physical activity }(\mathrm{N}=30)\end{array}$} & $\begin{array}{l}>1 \text { hour / } \\
\text { day }\end{array}$ & 13 & 43 \\
\hline & $\begin{array}{l}45-60 \text { mins } \\
\text { / day }\end{array}$ & 8 & 27 \\
\hline & $\begin{array}{l}30-45 \text { mins } \\
\text { / day }\end{array}$ & 4 & 13 \\
\hline & $\begin{array}{c}<30 \text { mins / } \\
\text { day }\end{array}$ & 5 & 17 \\
\hline
\end{tabular}

The permanent residence of the majority of participants was city (78\%). Most of them (86\%) belonged to Hindu religion followed by $9.2 \%$ Christian and $4 \%$ Muslim. The majority $(90.2 \%)$ of study participants belonged to a nuclear family. (Table. 1)
Out of 174 study participants, nearly one third (27\%) were found to be obese (BMI > 25) as per Asia-Pacific perspective given by WHO. Nearly one fourth $(23.6 \%)$ were found to be overweight. Among the total study participants, 89 $(51.2 \%)$ were involved in some kind of physical activity. Out of 89 physically active students, more than half (66.3\%) were doing moderate physical activity and one third (33.7\%) were doing intense physical activity. (Table 2) Majority (61.5\%) of study participants took three main meals and $68.4 \%$ had one snack regularly. More than half of the participants (68.4\%) \& (59.2\%) had one serving of vegetables and fruits respectively. Nearly one third (31.6\%) participants skipped breakfast $>3$ times / week or daily and $27.6 \%$ participants were having junk food $>3$ times / week or daily. (Table.3)

Among the study participants, $59.2 \%$ showed healthconscious behaviour about food consumption occasionally. $162(93.1 \%)$ perceived that it is important to have breakfast and $145(83.4 \%)$ aspired to take breakfast regularly. The majority (87.9 \%) knew that taking breakfast regularly influences the body functioning, physical and mental health. More than half (59.8\%) of the participants perceived skipping breakfast affected memory. (Table 4)

\begin{tabular}{|c|c|c|c|}
\hline \multicolumn{2}{|c|}{ Variables } & Frequency & Percentage \\
\hline \multirow{4}{*}{$\begin{array}{l}\text { Frequency of main } \\
\text { meals(daily) }\end{array}$} & One & 15 & 8.6 \\
\hline & Two & 46 & 26.4 \\
\hline & Three & 107 & 61.5 \\
\hline & Four & 6 & 3.4 \\
\hline \multirow{4}{*}{$\begin{array}{l}\text { Frequency of snacks } \\
\text { (daily) }\end{array}$} & One & 119 & 68.4 \\
\hline & Two & 43 & 24.7 \\
\hline & Three & 8 & 4.6 \\
\hline & Four & 4 & 2.3 \\
\hline \multirow{4}{*}{$\begin{array}{l}\text { Servings of vegetables } \\
\text { (daily) }\end{array}$} & One & 103 & 59.2 \\
\hline & Two & 53 & 30.5 \\
\hline & Three & 18 & 10.3 \\
\hline & Four & 0 & 0 \\
\hline \multirow{4}{*}{ Servings of fruits (daily) } & One & 134 & 77 \\
\hline & Two & 31 & 17.8 \\
\hline & Three & 8 & 4.6 \\
\hline & Four & 1 & 0.6 \\
\hline \multirow{4}{*}{$\begin{array}{l}\text { Skipping of breakfast (in } \\
\text { a week) }\end{array}$} & Daily & 30 & 17.2 \\
\hline & $>3$ days / week & 25 & 14.4 \\
\hline & $<3$ days / week & 54 & 31 \\
\hline & Not at all & 65 & 37.4 \\
\hline \multirow{4}{*}{$\begin{array}{l}\text { Consumption of junk } \\
\text { foods (in a week) }\end{array}$} & Daily & 9 & 5.2 \\
\hline & $>3$ days / week & 39 & 22.4 \\
\hline & $<3$ days / week & 103 & 59.2 \\
\hline & Not at all & 23 & 13.2 \\
\hline \multirow{4}{*}{$\begin{array}{l}\text { Consumption of } \\
\text { chocolate / refined } \\
\text { sugars (in a week) }\end{array}$} & Daily & 26 & 14.9 \\
\hline & $>3$ days / week & 27 & 15.5 \\
\hline & $<3$ days / week & 90 & 41.7 \\
\hline & Not at all & 31 & 17.8 \\
\hline \multirow{4}{*}{$\begin{array}{l}\text { Consumption of baked } \\
\text { foods (in a week) }\end{array}$} & Daily & 13 & 7.5 \\
\hline & $>3$ days / week & 29 & 16.7 \\
\hline & $<3$ days / week & 105 & 60.3 \\
\hline & Not at all & 27 & 15.5 \\
\hline \multirow{4}{*}{$\begin{array}{l}\text { Consumption of soft } \\
\text { drinks (in a week) }\end{array}$} & Daily & 9 & 5.2 \\
\hline & $>3$ days / week & 23 & 13.2 \\
\hline & $<3$ days / week & 64 & 36.8 \\
\hline & Not at all & 78 & 44.8 \\
\hline \multirow{4}{*}{$\begin{array}{l}\text { Consumption of dairy } \\
\text { items (in a week) }\end{array}$} & Daily & 22 & 12.6 \\
\hline & $>3$ days / week & 42 & 24.1 \\
\hline & $<3$ days / week & 84 & 48.3 \\
\hline & Not at all & 26 & 14.9 \\
\hline
\end{tabular}

\section{Regression Applied}

On bivariate regression analysis, the age group of 22 - 23 years (OR: 19.5, 95 \% C.I.2.08, 183.70) was found to be significantly associated with obesity. Gender, place of residence, consumption of junk food, skipping of breakfast meal ( $>3$ times per week) (OR: 0.45, 95 \% C.I.:0.23, 0.90) and physical activity levels were not found to be associated with obesity. (Table 5) 


\begin{tabular}{|c|c|c|c|}
\hline \multicolumn{2}{|c|}{ Perception about Breakfast } & Frequency & Percentage \\
\hline \multirow{3}{*}{ Health conscious behaviour about food consumption } & Always & 42 & 24.1 \\
\hline & Never & 29 & 16.7 \\
\hline & Sometimes & 103 & 59.2 \\
\hline \multirow{2}{*}{ Affects work efficacy / concentration if not consumed } & Yes & 126 & 71.8 \\
\hline & No & 48 & 28.2 \\
\hline \multirow{2}{*}{ Breakfast meal is important to have regularly } & Yes & 162 & 93.1 \\
\hline & No & 12 & 6.9 \\
\hline \multirow{2}{*}{ Influences body functioning, physical, mental health } & Yes & 153 & 87.9 \\
\hline & No & 21 & 12.1 \\
\hline \multirow{2}{*}{ Feeling physically weaker when not consumed } & Yes & 129 & 74.2 \\
\hline & No & 45 & 25.8 \\
\hline \multirow{2}{*}{ Skipping affects memory } & Yes & 104 & 59.8 \\
\hline & No & 70 & 40.2 \\
\hline \multirow{2}{*}{ Skipping affects school attendance } & Yes & 76 & 43.7 \\
\hline & No & 98 & 56.3 \\
\hline \multirow{2}{*}{ Skipping affects concentration } & Yes & 130 & 74.7 \\
\hline & No & 44 & 25.3 \\
\hline \multirow{2}{*}{ Skipping affects physical activity } & Yes & 119 & 68.4 \\
\hline & No & 55 & 31.6 \\
\hline \multirow{2}{*}{ Wish to have breakfast daily } & Yes & 145 & 83.4 \\
\hline & No & 29 & 16.6 \\
\hline \multicolumn{4}{|c|}{ Table 4. Perception about Breakfast ( $N=174)$} \\
\hline
\end{tabular}

\begin{tabular}{|c|c|c|c|c|c|c|}
\hline \multicolumn{2}{|c|}{ Variables } & $\begin{array}{l}\text { Present } \\
\text { No. (\%) }\end{array}$ & $\begin{array}{l}\text { Absent } \\
\text { No. (\%) }\end{array}$ & $\begin{array}{l}\text { ? Total } \\
\text { N (\%) }\end{array}$ & $\begin{array}{c}\text { Crude } \\
\text { Odds Ratio }\end{array}$ & $\begin{array}{c}\text { Adjusted } \\
\text { Odds Ratio }\end{array}$ \\
\hline \multirow{2}{*}{ Skipping of Breakfast } & Yes & $23(21.1)$ & $86(78.9)$ & $109(100)$ & $0.45(0.23,0.90)$ & $0.64(0.27,1.50)$ \\
\hline & No & $24(36.9)$ & $41(63.1)$ & $65(100)$ & 1 & 1 \\
\hline \multirow{3}{*}{ Age group } & $18-19$ & $12(20.3)$ & $47(79.7)$ & $59(100)$ & 1 & 1 \\
\hline & $20-21$ & $30(27.5)$ & $79(72.5)$ & $109(100)$ & $1.48(0.69,3.18)$ & $1.68(0.73,03.82)$ \\
\hline & $22-23$ & $5(83.3)$ & $1(16.7)$ & $6(100)$ & $19.5(2.08,183.70)$ & $16.82(1.56,180.55)$ \\
\hline \multirow[b]{2}{*}{ Gender } & Male & $22(34.9)$ & $41(65.1)$ & $63(100)$ & $1.84(0.93,03.65)$ & $2.02(0.93,4.41) 1$ \\
\hline & Female & $25(22.5)$ & $86(77.5)$ & $111(100)$ & 1 & 1 \\
\hline \multirow{2}{*}{ Place of residence } & Hosteller & $17(20.2)$ & $67(79.8)$ & $84(100)$ & $0.50(0.25,1.01)$ & $0.57(0.25,1.30)$ \\
\hline & Day scholar & $30(33.3)$ & $60(66.7)$ & $90(100)$ & 1 & 1 \\
\hline \multirow[b]{2}{*}{ Taking Junk food } & Yes & $9(18.8)$ & $39(81.2)$ & $48(100)$ & $0.53(0.23,1.21)$ & $0.53(0.21,1.35)$ \\
\hline & No & $38(30.2)$ & $88(69.8)$ & $126(100)$ & 1 & 1 \\
\hline \multirow{2}{*}{ Physical activity } & Active & $27(30.3)$ & $62(69.7)$ & $89(100)$ & $1.41(0.72,2.77)$ & $1.34(0.64,2.80)$ \\
\hline & Inactive & $20(23.5)$ & $65(76.5)$ & $85(100)$ & 1 & 1 \\
\hline \multirow{2}{*}{ Type of family } & Nuclear & $39(24.8)$ & $118(75.2)$ & $157(100)$ & 1 & 1 \\
\hline & Joint & $8(47.1)$ & $9(52.9)$ & $17(100)$ & $2.68(0.97,7.44)$ & $2.77(0.87,8.74)$ \\
\hline & & termina & esity am & dy Partici & $V=174)$ & \\
\hline
\end{tabular}

\section{DISCUSSION}

In the present study, we studied 174 undergraduate medical students with majority ( $63 \%$ ) belonging to the age group of $20-21$ years and among them (63.8\%) were females. BMI was measured using Asia-Pacific guidelines by $\mathrm{WHO}^{17,18}$ for obesity. The prevalence of overweight $(23.6 \%)$ and obesity (27\%) was found to be higher in females compared to males. Our results corroborate with findings that were reported by Amruth M et al. ${ }^{19}$ where prevalence of overweight (18.2\%) and obesity (20.3\%) has been observed more among female medical students compared to males. Among medical students in Kerala, in which $18.2 \%$ and $20.3 \%$ belonged to overweight and obesity group respectively. Kumar CA et al. found that 9.5 $\%$ of medical students had obesity (BMI $>25$ ) in a study done in Andhra Pradesh. ${ }^{20}$ Similarly, Dhanuraja V et al. found that $8.4 \%$ of medical students in Chennai had obesity (BMI > 25). ${ }^{21}$ In a study conducted in Delhi by Chhabra P et al. found that only two percent of medical students had obesity. ${ }^{22}$ In contrast, Gopal Krishnan S et al. found a lower prevalence of overweight (11.7\%) and obesity (2\%) among medical students in Malaysia. ${ }^{23}$ This difference could be due to different study parameters used in the study such as sample size and study timeline. In this study, we also found that nearly half $(51.1 \%)$ of the participants were physically active and the majority $(66.3 \%)$ were engaged in moderate physical activity. Similar findings of physical activity pattern were reported by Amruth $\mathrm{M}$ et al. (54.5\%) and Gupta S et al. (46 \%) among medical students. ${ }^{19,24}$

Around sixty-one percent of the participants maintained proper three meals dietary pattern for the whole day.
Interestingly, $17.2 \%$ participants were skipping breakfast daily, whereas $14.4 \%$ participants were skipping breakfast for more than three days in a week. Our findings overlapped with that of Kumar CA et al..$^{20}$ and Amruth M et al. ${ }^{19}$ where they found that $44.2 \%$ and $67.2 \%$ of the participants were taking three meals daily respectively. However, Amruth et al. ${ }^{19}$ found a lower prevalence of daily breakfast skipping $(2.3 \%)$ and more than thrice per week breakfast skipping (3.4\%). ${ }^{19}$ Contrastingly, a higher proportion of skipping of breakfast was reported by Sofar SM et al. (87.6 \%) and Manal Ahmad et al. $(88.8 \%)^{25,26}$ This strikingly different results could be due to differences in study settings, assessment methods, and sample size. Multivariate analysis showed that age group $(22-23$ years) (OR: 19.5, $95 \% \mathrm{CI} ; 2.08,183.70$ ) was the only factor associated with obesity. Skipping breakfast (OR, 0.45, $95 \%$ CI: $0.23,0.90$ ) was not associated with obesity. Our findings were similar to Manal Ahmad et al. ${ }^{26}$ where they concluded that BMI had no relation with meals.

With regard to the importance and side effects of skipping breakfast, our findings contradict with Sofar SM et al. who found a lower level of awareness about the importance of breakfast (27.5\% mentioned about its benefits in improving and $4.9 \%$ mentioned it directly help in physical activity) and its side effects of skipping it (19.6\%) among participants. ${ }^{25}$

Despite our study and previous study ${ }^{26}$ findings that no association was found between BMI and eating habits, it has been proven that skipping breakfast could cause not only low energy levels in the morning but also a decrease in total energy expenditure which can result in the development of obesity. In addition, skipping meals reduces overall calorie consumption and results in high blood sugar level. Breakfast is considered 
to be an important meal for building immunity and keeping medical students away from infections in and around the hospital campus.

\section{CONCLUSIONS}

Our study found that more than one-fourth participants were obese and one thirds were skipping breakfast daily or more than thrice a week. There was no association between obesity and skipping of breakfast meal. However, the importance of breakfast meal in a day cannot be undermined. Awareness programs are tailored to prevent obesity and overweight among students to practice healthy eating habits.

\section{Limitations}

The present study had certain limitations like Hawthorne bias and Recall bias which might directly affect the study results. Our study used BMI criteria that is specific for the Asian population for classification of obesity, due to which the results may not be generalizable.

Data sharing statement provided by the authors is available with the full text of this article at jemds.com.

Financial or other competing interests: None.

Disclosure forms provided by the authors are available with the full text of this article at jemds.com.

We are thankful to the MBBS students who participated in the study.

\section{REFERENCES}

[1] Zilberter T, Zilberter EY. Breakfast: to skip or not to skip. Front Public Health 2014;2:59.

[2] Timlin MT, Pereira MA. Breakfast frequency and quality in the etiology of adult obesity and chronic diseases. Nutr Rev 2007;65(6 Pt 1):268-81.

[3] Marangoni F, Poli A, Agostoni C, et al. A consensus document on the role of breakfast in the attainment and maintenance of health and wellness. Acta Biomed 2009;80(2):166-71.

[4] Chen J, Cheng J, Liu Y, et al. Association between breakfast eating habits and health-promoting lifestyle, suboptimal health status in Southern China: a population based, cross sectional study. J Transl Med 2014;12:348.

[5] Dubois L, Girard M, Kent MP, et al. Breakfast skipping is associated with differences in meal patterns, macronutrient intakes and overweight among pre-school children. Public Health Nutr 2009;12(1):19-28.

[6] Silliman K, Rodas-Fortier K, Neyman M. Survey of dietary and exercise habits and perceived barriers to following a healthy lifestyle in a college population. Cal J Health Promot 2004;2(2):10-9.

[7] Sakamaki R, Toyama K, Amamoto R, et al. Nutritional knowledge, food habits and health attitude of Chinese university students-a cross sectional study. Nutr J 2005;4:4.

[8] Gross SM, Bronner Y, Welch C, et al. Breakfast and lunch meal skipping patterns among fourth grade children from selected public schools in urban, suburban and rural Maryland. J Am Diet Assoc 2004;104(3):420-3.

[9] Savige G, MacFarlane A, Ball K, et al. Snacking behaviours of adolescents and their association with skipping meals. Int J Behav Nutr Phys Act 2007;4:36.

[10] Cho S, Dietrich M, Brown CJP, et al. The effect of breakfast type on total daily energy intake and body mass index: results from the Third National Health and Nutrition Examination Survey (NHANES III). J Am Coll Nutr 2003;22(4):296-302.

[11] Purslow LR, Sandhu MS, Forouhi N, et al. Energy intake at breakfast and weight change: prospective study of 6,764 middle-aged men and women. Am J Epidemiol 2008;167(2):188-92.

[12] Mekary RA, Giovannucci E, Willett WC, et al. Eating patterns and type 2 diabetes risk in men: breakfast omission, eating frequency and snacking. Am J Clin Nutr 2012;95(5):1182-9.

[13] Yoko W, Isao S, Henmi I, et al. Skipping breakfast is correlated with obesity. J Rural Med 2014;9(2):51-8.

[14] Burazeri G, Hyska J, Mone I, et al. Breakfast skipping is an independent predictor of obesity but not overweight among children in a Southeastern European population. Int J Vitam Nutr Res 2016;86(3-4):242-8.

[15] Boo NY, Chia GJ, Wong LC, et al. The prevalence of obesity among clinical students in a Malaysian medical school. Singapore Med J 2010;51(2):126-32.

[16] Daniel WW, Cross CL. Determination of sample size for estimating proportions. Biostatistics A Foundation for Analysis in the Health Sciences 1999;8:189-90.

[17] WHO. Regional Office for the Western Pacific. The AsiaPacific perspective: redefining obesity and its treatment. Melbourne: Health Communications Australia 2000.

[18] WHO Expert Consultation. Appropriate body mass index for Asian populations and its implications for policy and intervention strategies. Lancet 2004;363(9403):157-63.

[19] Amruth M, Kumar A. A cross-sectional study on BMI and eating habits among students in a medical college in Kerala. Int J Community Med Public Health 2019;6(3):1285-94.

[20] Kumar CA, Revannasiddaiah N, Gopi A, et al. A crosssectional study on the dietary factors and their association with body mass index among undergraduate medical students in a medical college. Int J Res Health Sci 2014;2(2):591-8.

[21] Dhanuraja V, Gopalakrishnan S, Umadevi R. A study on prevalence \& determinants of overweight/obesity among medical college students in Kancheepuram district. Nat J Res Com Med 2017;6(1):33-6.

[22] Chhabra P, Grover VL, Aggarwal K, et al. Nutritional status and blood pressure of medical students in Delhi. Indian J Community Med 2006;31(4):248-51.

[23] Gopalakrishnan S, Ganeshkumar P, Prakash MVS, et al. Prevalence of overweight/obesity among the medical students, Malaysia. Med J Malaysia 2012;67(4):442-4.

[24] Gupta S, Ray TG, Saha I. Overweight, obesity and influence of stress on body weight among undergraduate medical students. Indian J Community Med 2008;34(3):255-7.

[25] Sofar SM, Abd El Hafeez NAA. Relations between skipping breakfast, academic performance and body mass index among undergraduate university nursing students. Journal of Nursing and Health Science 2019;8(4):32-42. 
[26] Mahmoud MH, Taha AS. The association between eating habits and body mass index among nursing students. Journal of Nursing and Health Science 2017;6(3):14-6. 